\title{
EFEKTIFITAS MULTIMEDIA PEMBELAJARAN INTERAKTIF PKK DALAM MENINGKATKAN KREATIVITAS BERWIRAUSAHA SISWA SMK
}

\author{
Calista Devi Handaru' ${ }^{1)}$, Pujiriyanto ${ }^{2)}$ \\ Fakultas Ilmu Pendidikan, Universitas Negeri Yogyakarta ${ }^{1) \& 2)}$ \\ e-mail: calistadevi.2018@ student.uny.ac.id ${ }^{1)}$, pujiriyanto@ uny.ac.id ${ }^{2)}$
}

\begin{abstract}
Abstrak
Penelitian ini bertujuan untuk mengetahui keefektifan multimedia pembelajaran interaktif dalam meningkatkan kreativitas berwirausaha siswa SMK. Penelitian ini merupakan jenis penelitian kuantitatif dengan menggunakan metode eksperimen. Desain penelitian yang digunakan dalam penelitian ini adalah Pre-Experimental Design dengan model One-Group Pretest-Posttest Design. Populasi dalam penelitian ini adalah semua siswa Klaten kelas XI Program Keahlian Bisnis Daring dan Manajemen Jurusan Akuntansi dan Keuangan Lembaga (AKL) dengan sampel sebanyak 30 siswa dengan jumlah perwakilan perkelas sebanyak 10 siswa. Teknik pengumpulan data yang digunakan yaitu tes. Tes berisi soal yang mengukur kreativitas berwirausaha siswa melalui lima aspek; 1) keaslian (originality), 2) kelancaran (fluency), 3) keluwesan (fleksibility), 4) Penguraian (elaboration), dan 5) Perumusan kembali (redefinition). Teknik analisis data yang digunakan dalam penelitian ini yaitu analisis deskriptif kuantitatif. Hasil penelitian menunjukan bahwa multimedia pembelajaran interaktif PKK memiliki efektivitas yang tinggi dalam meningkatkan kreativitas berwirausaha siswa yang dibuktikan dengan adanya peningkatan rerata skor pada posttest di setiap aspek kreativitas berwirausaha dan hasil uji wilcoxon memperoleh nilai Asymp.Sig. (2tailed) < 0,05 di semua aspek kreativitas berwirausaha. Hal ini berarti multimedia pembelajaran interaktif PKK dapat dijadikan sebagai alternatif media pembelajaran mata pelajaran PKK dalam meningkatkan kreativitas berwirausaha siswa SMK.
\end{abstract}

Kata Kunci: multimedia pembelajaran interaktif, PKK, kreativitas berwirausaha

\section{THE EFFECTIVENESS OF INTERACTIVE LEARNING MULTIMEDIA TO ENHANCE VOCATIONAL STUDENT'S ENTREPRENEURIAL CREATIVITY}

\begin{abstract}
This study aims to determine the effectiveness of interactive learning multimedia to enhance entrepreneurial creativity of vocational school students. It employed quantitative research that used experimental methods. The research design being used was Pre-Experimental Design with One-Group Pretest-Posttest Design model. The population in this study were all the XI graders students of the Online Business and Management Expertise Program, Department of Accounting and Financial Institutions $(A K L)$ with the sample of 30 students with 10 class representatives. The data collection technique used in this study was test. The test contains questions that measure students' entrepreneurial creativity through five aspects; 1) originality, 2) fluency, 3) flexibility, 4) elaboration, and 5) redefinition. The data analysis technique used in this research was quantitative descriptive analysis. The results showed that the interactive learning multimedia PKK have high effectiveness to enhance students' entrepreneurial creativity as evidenced by the increase of an average score posttest. Furthermore, the result of Wilcoxon signed-rank test obtained has a value of Asymp.Sig. (2-tailed) <0,05 in all of the entrepreneurial creativity aspect. It means that interactive multimedia PKK learning can be used as an alternative learning media for PKK subjects to enhance vocational student's entrepreneurial creativity.
\end{abstract}

Keywords: interactive learning multimedia, PKK, entrepreneurial creativity

\section{PENDAHULUAN}

Pada saat ini Indonesia sedang menjalankan era revolusi industri 4.0 yang ditandai dengan menjamurnya perkembangan suatu sistem berupa digitalisasi yang di implementasikan pada semua sektor kehidupan masyarakat. Pendidikan menjadi salah satu aspek yang memegang peran penting dalam menggerakan roda perubahan era revolusi industri 4.0. Sumber daya manusia (SDM) pada era ini harus mampu mengikuti perkembangan dan cepat beradaptasi, sehingga dapat bersaing dalam lingkungan global.

Dalam menjalankan era revolusi industri 4.0 pemerintah melahirkan (roadmap) peta jalan yang bernama Making Indonesia 4.0. Making Indonesia 4.0 merupakan langkah kolaboratif yang bertujuan untuk 
meningkatkan kompetensi sumber daya manusia dalam menghadapi era industri 4.0. Salah satu contohnya adalah dengan melakukan program link and match antara pendidikan dan industri.

Pendidikan menengah kejuruan (SMK) menjadi salah satu sasaran dan perhatian utama pemerintah dalam menerapan program link and match antara pendidikan dan industri. Hal ini dikarenakan SMK merupakan lembaga pendidikan yang mempunyai fokus untuk mempersiapkan dan melahirkan lulusan yang siap bekerja. Menurut Undang-undang No. 20 Tahun 2003 tentang Pendidikan Nasional pasal 18 dikatakan bahwa pendidikan kejuruan merupakan pendidikan menengah yang mempersiapkan siswa terutama untuk bekerja dalam bidang tertentu dimana pendidikannya berbasis pada pengembangan keahlian.

Senada dengan yang dinyatakan oleh National Council for Research into Vocational Education USA (1981) bahwa pendidikan kejuruan yaitu bentuk subsistem dari pendidikan yang mempunyai tugas khusus untuk membantu siswa dalam mempersiapkan dirinya dalam memasuki dunia kerja. Pada saat ini pendidikan SMK telah mengarah pada kebutuhan global abad 21. Kementerian Pendidikan dan Kebudayaan merancang paradigma pembelajaran abad 21 dengan menekankan kemampuan siswa dalam mencari tahu informasi dari beragam sumber, berpikir analitis, kerjasama dan mampu untuk berkolaborasi dalam menyelesaikan masalah (Litbang Kemdikbud, 2013).

Hal tersebut sejalan dengan karakteristik skills masyarakat abad 21 yang dipublikasikan Partnership of 21st Century Skill (Trilling, 2009: 17) yang menyatakan pembelajar abad 21 harus mampu mengembangkan keterampilan kompetitif 4C yaitu, creativity (kreativitas), critical thinking (berpikir kritis), communication (komunikasi), dan collaboration (kolaborasi). Selain itu, pemerintah juga telah melahirkan kompetensi keahlian wajib berupa mata pelajaran Produk Kreatif dan Kewirausahaan (PKK).

Mata pelajaran ini bertujuan untuk mengembangkan dan meningkatkan kompetensi para siswa khususnya dalam aspek berwirausaha, sehingga siswa memiliki jiwa wiarusaha yang ditandai dengan mampu untuk berwirausaha secara mandiri dengan sikap dan mental yang unggul dan mampu bersaing secara baik dan mandiri. Melalui mata pelajaran ini siswa secara tidak langsung akan dirangsang untuk berpikir sesuai kecakapan berpikir abad 21.

Salah satunya adalah dengan cara melatih siswa untuk menghasilkan berbagai produk atau jasa. Direktorat Pembinaan SMK juga menyatakan bahwa mata pelajaran PKK dapat menghasilkan manusia terampil intelektual, tetapi juga yang inspiratifpragmatis. Oleh sebab itu mata pelajaran ini menjadi jalan alternatif dalam mempersiapkan lulusan professional dan mampu menciptakan lapangan kerja sendiri.

Berdasarkan observasi awal yang dilakukan penelliti diperoleh data bahwa dalam pelaksanaan pembelajaran PKK guru masih belum memanfaatkan media pembelajaran secara maksimal. Selain itu, metode konvesional berupa ceramah lebih sering digunakan dalam proses pembelajaran PKK. Padahal pembelajaran PKK seharusnya di arahkan pada kemampuan berpikir tingkat tinggi sehingga mampu membekali siswa dalam bersaing dengan dunia industri 4.0 .

Mata pelajaran PKK hendaknya berisi tentang bagaimana membangun minat dan keberanian dalam berwirausaha sesuai kompetensi keahlian, bukan sekedar tentang teori kewirausahaan atau teori manajemen bisnis. Fokus materi pelajaran PKK seharusnya adalah tentang pengembangan produk atau jasa, sehingga dibutuhkan rangsangan agar siswa mampu berpikir kreatif (Sarwa, 2018: 2).

Permasalahan tersebut berdampak pada tidak tercapainya tujuan pembelajaran lahirnya mata pelajaran PKK. Media pembelajaran hendaknya digunakan untuk memfasilitasi dan membantu dalam tercapainya tujuan pembelajaran PKK khususnya yang mampu merangsang kreativitas berwirausaha siswa. Menurut Hujair (2013: 7) media pembelajaran akan dapat mendukung proses pembelajaran 
karena media pembelajaran mempunyai fungsi untuk memberikan suasana belajar yang menyenangkan, tidak tertekan, santai, dan menarik, sehingga tujuan pembelajaran dapat tercapai. Martin dan Briggs (1986: 448) mengidentifikasikan media pembelajaran sebagai suatu cakupan dari beragam jenis sumber yang diperlukan untuk melakukan suatu proses komunikasi dengan siswa. Sumber tersebut dapat berupa perangkat keras seperti komputer dan perangkat lunak.

Menurut Smaldino, et. al., (2011: 7) media pembelajaran yaitu alat komunikasi yang membawa pesan yang berkaitan dengan pencapaian tujuan pembelajaran. Selanjutnya Sadiman (2011: 17) media pembelajaran memiliki fungsi sebagai alat untuk memperjelas penyajian pesan supaya tidak terlalu bersifat verbalisme, mengatasi keterbatasan ruang, waktu dan daya indra serta mampu menjadikan siswa bersifat aktif dalam proses pembelajaran. Hal ini dapat disimpulkan media pembelajaran yaitu alat yang digunakan sebagai perantara untuk mendukung dalam menyampaikan informasi kepada siswa berupa perangkat keras atau perangkat lunak yang akan membuat pembelajaran menjadi lebih mudah, efektif dan efisien.

Banyak alternatif media pembelajaran yang dapat digunakan untuk merangsang kreativitas. Salah satunya adalah multimedia pembelajaran. Menurut Surjono (2017: 41) multimedia pembelajaran interaktif merupakan kombinasi dari beberapa jenis media seperti teks, gambar, suara, animasi, video dan lain lain yang digabungkan secara terpadu dan sinergis melalui komputer atau peralatan elektronik lainnya untuk mencapai tujuan tertentu dan pengguna dapat berinteraksi secara aktif dengan program. Multimedia pembelajaran interaktif minimal memiliki dua komponen media yang berbeda. Selain itu, komponen tersebut harus diolah dan dipadukan secara sinergis menggunakan sistem berbasis elektronik atau komputer. Lebih lanjut Munir (2010: 233) mendefinisikan multimedia sebagai suatu sistem komputer yang dari perangkat keras dan perangkat lunak yang dapat memberi kemudahan untuk menggabungkan gambar, video, fotografi, grafik, dan animasi dengan suara, teks, dan data dengan dikendalikan oleh program yang ada di komputer.

(Darmawan, 2011: 33; Daryanto 2010: 53; Hackbarth, 1996) mengidentifikasikan karakteristi multimedia pembelajaran sebagai berikut; 1) multimedia berbentuk satu kesatuan media yang terdiri dari berbagai media sehingga kaya akan informasi 2) mempunyai sifat interaktifitas yang dapat memberikan penguatan dan respon balik kepada pengguna, 3) mempunyai sifat yang fleksibel dan mandiri yang berarti multimedia dapat digunakan secara individu maupun kelompok dan dapat dikembangkan sesuai karakteristik materi dan kebutuhan siswa, 4) multimedia pembelajaran merupakan media yang memiliki daya tarik tersendiri melalui penggunaan warna dan resolusi.

Mengacu dari pendapat ahli di atas, maka disimpulkan multimedia pembelajaran interaktif merupakan kombinasi dari berbagai jenis media yang saling terintegrasi untuk menyampaikan suatu informasi yaitu materi pembelajaran dengan menggunakan sistem berbasis komputer untuk mencapai tujuan pembelajaran. Multimedia pembelajaran interaktif melibatkan siswa untuk menjalankan atau mengoperasikan software melalui komputer secara mandiri ataupun kelompok sehingga siswa menjadi aktif saat proses pembelajaran.

Hal ini diperkuat oleh Saputri \& Saputri \& Hikmah (2019) dalam penelitiannya yang mengatakan bahwa pembelajaran menggunakan multimedia pembelajaran interaktif lebih bermakna, interaktif, menarik dan menyenangkan sehingga mudah untuk mengembangkan kreativitas pada siswa. Oleh karena itu multimedia pembelajaran interaktif sangat relevan apabila digunakan sebagai media dalam pembelajaran PKK.

Pembelajaran PKK media yang mampu memberikan rangsangan untuk meningkatkan kreativitas yang ada di dalam diri siswa. Morris (2006, 5) memaparkan kreativitas pada pelaksanaan pembelajaran menjadi hal penting 
yang harus diperhatikan oleh pendidik karena kreativitas dapat melahirkan dorongan dan ekspektasi yang tinggi pada siswa. Selain itu, kreativitas mampu menjadikan proses pembelajaran lebih menarik dan menginspirasi. Otte $(1966,40)$ menjelaskan bahwa kreativitas dalam pembelajaran mampu diwujudkan dengan mendatangkan beragam pengalaman belajar bagi siswa.

Pada penelitian ini kreativitas dikhususkan pada kreativitas berwirausaha yang pada penelitian ini merujuk pada dimensi proses kreatif dengan output berupa ide atau gagasan kreatif. Kemunculan ide atau gagasan kreatif merupakan bentuk dari kemampuan berpikir tingkat tinggi atau HOTs (High Order Thingking skills). Menurut King, et. al., (2013: 13) berpikir kreatif memerlukan situasi belajar yang sama dengan berpikir tingkat tinggi.

Sedangkan kreativitas wirausaha menurut Basrowi (2016: 39-40), dapat dilihat melalui tiga hal, antara lain: 1) Menciptakan, yaitu proses melahirkan sesuatu dari sesuatu yang tidak ada menjadi ada. 2) Memodifikasi, yaitu mencari berbagai cara untuk membentuk fungsi baru atau menjadikan sesuatu menjadi berbeda dari yang sudah ada. 3) Mengkombinasikan dua hal atau lebih yang sebelumnya tidak saling berhubungan. Kreativitas wirausaha dalam penelitian ini mempunyai definisi sebagai kemampuan dalam menciptakan, mengembangkan ide, gagasan atau peluang untuk memulai suatu usaha yang dapat menambah nilai dan bermanfaat bagi kehidupan.

Indikator yang akan dijadikan untuk mengukur kreativitas wirausaha dalam penelitian ini adalah 1) kelancaran (fluency), yaitu kemampuan untuk menghasilkan beragam ide atau gagasan dalam menciptakan produk usaha, 2) keaslian (originality) yaitu ide atau gagasan produk usaha yang dihasilkan adalah sesuatu yang baru atau pengembangan dari yang sudah ada 3) keluwesan (fleksibility), yaitu kemampuan untuk menemukan berbagai peluang dalam usaha 4) Penguraian (elaboration), kemampuan menguraikan peluang dan ancaman yang muncul pada suatu usaha secara detail dan 5) Perumusan kembali (redefinition), yaitu kemampuan untuk meninjau kembali usaha yang telah dikembangkan. Kelima indikator tersebut akan menjadi patokan untuk mengembangkan instrumen kreativitas berwirausaha dalam penelitian ini.

Tujuan penelitian ini ialah untuk mengetahui keefektifan multimedia pembelajaran interaktif dalam meningkatkan kreativitas berwirausaha siswa SMK berdasarkan analisis peningkatan kreativitas berwirausaha siswa antara sebelum dan sesudah menggunakan multimedia pembelajaran interaktif PKK.

\section{METODE}

\section{Jenis Penelitian}

Penelitian ini merupakan jenis penelitian kuantitatif dengan menggunakan metode eksperimen. Menurut Sugiyono (2012:107) metode penelitian eksperimen yaitu metode yang digunakan untuk mencari pengaruh perlakuan tertentu terhadap yang hal lain yang terkendali. Hal ini berarti bahwa penelitian eksperimen ini melihat pengaruh subjek yang sengaja diberi perlakuan secara terarah.

Desain penelitian yang digunakan dalam penelitian ini adalah Pre-Experimental Design dengan model desain One-Group PretestPosttest Design. Dalam desain ini, subjek akan diintruksikan untuk mengerjakan pretest, setelah itu subjek diberi perlakuan /treatment dan terakhir subjek kembali diintruksikan untuk mengerjakan posttest. Berikut merupakan tabel desain penelitian one group pretest posttest:

Tabel 1. Desain Penelitian One Group Pretest Posttest

\begin{tabular}{|c|c|c|}
\hline Pretest & Treatment & Posttest \\
\hline $\mathrm{O}_{1}$ & $\mathrm{X}$ & $\mathrm{O}_{2}$ \\
\hline
\end{tabular}

Sumber: Dantes (2017: 14)

Keterangan:

$\mathrm{O}_{1}$ (Pretest) : Nilai sebelum mendapat perlakuan (treatment).

$\mathrm{O}_{2}$ (Posttest) : Nilai setelah mendapat perlakuan (treatment). 
$\mathrm{X}($ Treatment $)$ : Perlakuan dengan menerapkan proses pembelajaran menggunakan multimedia pembelajaran interaktif PKK.

\section{Subjek Penelitian}

Pengambilan sampel dilakukan dengan teknik proportionate stratified random sampling. Hal ini dilakukan dengan pertimbangan karena yang menjadi populasi dalam penelitian ini yaitu siswa Klaten kelas XI Program Keahlian Bisnis Daring dan Manajemen Jurusan Akuntansi dan Keuangan Lembaga (AKL) yang terbagi menjadi 3 kelas antara lain AKL1, AKL2 dan AKL3. Ketiga kelas tersebut mewakilkan sampel dengan proporsi yang sama.

Prosedur pengambilan sampel adalah melalui undian. Selain itu, siswa memperoleh kurikulum yang sama sehingga materi pelajaran dan waktu pelajaran tidak berbeda antara yang satu dengan lainnya. Berdasarkan teknik pengambilan sampel di dapatkan 30 siswa dengan jumlah perwakilan perkelas sebanyak 10 siswa.

\section{Teknik Pengumpulan Data dan Instrumen}

Teknik pengumpulan data dalam penelitian ini adalah dengan menggunakan tes. Tes dilakukan sebanyak dua kali yaitu sebelum (pretest) dan sesudah (posttest) menggunakan multimedia pembelajaran interaktif PKK. Tes yang digunakan pada berbentuk isian yang juga merupakan instrumen dalam penelitian ini.

Dalam tes berisi soal yang mengukur kreativitas berwirausaha siswa melalui lima aspek, 1) kelancaran (fluency), yaitu kemampuan untuk menghasilkan beragam ide, 2) keaslian (originality) yaitu sesuatu yang baru atau pengembangan dari yang sudah ada 3) keluwesan (fleksibility), kemampuan untuk menemukan berbagai peluang 4) Penguraian (elaboration), kemampuan menguraikan peluang dan ancaman yang muncul pada suatu usaha secara detail dan 5) Perumusan kembali (redefinition), kemampuan untuk meninjau kembali kemudian menganalisis suatu usaha. Sedangkan pemberian nilai berpedoman pada instrumen kreativitas berwirausaha yang telah divalidasi expert judgement yaitu Dosen Teknologi Pembelajaran S2 UNY.

\section{Teknik Analisis Data}

Teknik analisis data yang digunakan dalam penelitian ini yaitu analisis deskriptif kuantitatif. Langkah awal dalam analisis data yaitu menghimpun skor hasil penilaian dari expert judgement yaitu dua orang guru Mata Pelajaran PKK dan peneliti. Kemudian menentukan kriteria kreatifitas berwirausaha dengan berpatokan pada tabel di bawah ini:

Tabel 2. Kriteria Kreativitas Berwirausaha

\begin{tabular}{|c|c|}
\hline Interval & Kriteria \\
\hline $3,25<\mathrm{X} \leq 4,00$ & Sangat Kreatif \\
\hline $2,75<\mathrm{X} \leq 3,25$ & Kreatif \\
\hline $2,25<\mathrm{X} \leq 2,75$ & Kurang Kreatif \\
\hline $1,75<\mathrm{X} \leq 2,25$ & Sangat Kurang Kreatif \\
\hline
\end{tabular}

Setelah hasil analisis peningkatan kreativitas berwirausaha dilakukan maka tahap selanjutnya menganalisis perbedaan pretest dan posttest yang dilakukan dengan menggunakan uji wilcoxon atau disebut wilcoxon signed rank test. Uji ini termasuk bagian dari metode statistik non parametrik sehingga tidak menggunakan uji prasyarat seperti uji normalitas dan uji homogenitas.

Pengujian ini dilakukan sebagai bukti empiris apakah terdapat perbedaan kreativitas berwirausaha siswa sebelum dan sesudah siswa menggunakan multimedia pembelajaran interaktif PKK. Adapun hipotesis dalam penelitian ini yaitu:

Hipotesis Alternatif (Ha): Terdapat perbedaan kreativitas berwirausaha siswa sebelum dan sesudah menggunakan multimedia pembelajaran interaktif PKK, yang berarti produk tersebut efektif digunakan untuk meningkatkan kreativitas berwirausaha siswa. Hipotesis Nol (Ho) : Tidak terdapat perbedaan kreativitas berwirausaha siswa sebelum dan sesudah menggunakan multimedia pembelajaran interaktif PKK. yang berarti produk tersebut tidak efektif digunakan untuk meningkatkan kreativitas berwirausaha siswa. 


\section{HASIL DAN PEMBAHASAN}

Hasil

Berdasarkan hasil penelitian menunjukkan bahwa multimedia pembelajaran interaktif PKK dapat meningkatan kreativitas siswa. Hal ini dapat dilihat dari hasil perhitungan yang dilakukan oleh tiga analis yaitu dua guru Mata Pelajaran PKK dan peneliti. Hasil tersebut dituangkan dalam tabel 3, tabel 4, tabel 5 dan tabel 6 .

Tabel 3. Rekap Hasil Analis 1

\begin{tabular}{|c|l|l|c|c|}
\hline \multirow{2}{*}{$\begin{array}{c}\text { Aspek } \\
\text { Penilaian }\end{array}$} & $\begin{array}{c}\text { Jml } \\
\text { Skor }\end{array}$ & $\begin{array}{c}\text { Rera } \\
\text { ta }\end{array}$ & Ket \\
\hline \multirow{2}{*}{ Ori } & Pre & 168 & 1,87 & SKK \\
\cline { 2 - 5 } & Post & 299 & 3,32 & SK \\
\hline \multirow{2}{*}{ Flue } & Pre & 188 & 1,57 & SKK \\
\cline { 2 - 5 } & Post & 385 & 3,21 & K \\
\hline \multirow{2}{*}{ Flex } & Pre & 178 & 1,98 & SKK \\
\cline { 2 - 5 } & Post & 335 & 3,72 & SK \\
\hline \multirow{2}{*}{ Elab } & Pre & 156 & 1,73 & SKK \\
\cline { 2 - 5 } & Post & 296 & 3,29 & SK \\
\hline \multirow{2}{*}{ Red } & Pre & 97 & 1,62 & SKK \\
\cline { 2 - 5 } & Post & 192 & 3,20 & K \\
\hline
\end{tabular}

Keterangan tabel:
SK : (Sangat Kreatif)
K : (Kreatif)
KK : (Kurang Kreatif)
SKK : (Sangat Kurang Kreatif)

Dari perolehan data hasil analis 1 dapat diketahui hasil pretest dari kelima aspek yaitu aspek yaitu originality (keaslian), fluency (kelancaran), flexibility (keluwesan), elaboration (penguraian) dan redefinition (perumusan kembali) memperoleh rerata 1,87, $1,57,1,98,1,73$ dan 1,62. Sedangkan hasil posttest memperoleh rerata 3,32, 3,21, 1,98, $3,72,3,29$ dan 3,20. Hal ini menunjukan hasil analis 1 mempunyai perbedaan antara hasil pretest dan posttest yang berarti terdapat peningkatan kreativitas berwirausaha sebelum dan sesudah menggunakan multimedia pembelajaran interaktif PKK. Selanjutnya yaitu hasil analisis dari analisi 2. Berikut tabel rekap hasil analis 2 :
Tabel 4. Rekap Hasil Analis 2

\begin{tabular}{|c|l|l|c|c|}
\hline \multirow{2}{*}{$\begin{array}{c}\text { Aspek } \\
\text { Penilaian }\end{array}$} & $\begin{array}{c}\text { Jml } \\
\text { Skor }\end{array}$ & $\begin{array}{c}\text { Rera } \\
\text { ta }\end{array}$ & Ket \\
\hline \multirow{2}{*}{ Ori } & Pre & 166 & 1,84 & SKK \\
\cline { 2 - 5 } & Post & 302 & 3,36 & SK \\
\hline \multirow{2}{*}{ Flue } & Pre & 187 & 1,56 & SKK \\
\cline { 2 - 5 } & Post & 387 & 3,23 & K \\
\hline \multirow{2}{*}{ Flex } & Pre & 180 & 2 & SKK \\
\cline { 2 - 5 } & Post & 335 & 3,72 & SK \\
\hline \multirow{2}{*}{ Elab } & Pre & 154 & 1,71 & SKK \\
\cline { 2 - 5 } & Post & 295 & 3,28 & SK \\
\hline \multirow{2}{*}{ Red } & Pre & 100 & 1,67 & SKK \\
\cline { 2 - 5 } & Post & 193 & 3,22 & K \\
\hline
\end{tabular}

Pada hasil rekap analis 2 di atas menunjukan adanya perubahan skor dan rerata pada pretest dan posttest. Rerata pretest yang diperoleh pada semua aspek mempunyai kriteria yang tidak berbeda yaitu Sangat Kurang Kreatif. Sedangkan rerata yang diperoleh pada posttest termasuk ke dalam dua kriteria yaitu Sangat Kreatif pada aspek originality (keaslian), flexibility (keluwesan), elaboration (penguraian) dan Kreatif pada aspek fluency (kelancaran), dan redefinition (perumusan kembali). Hal serupa juga terjadi pada hasil analisis dari analis 3 . Berikut tabel hasil rekap tersebut:

Tabel 5. Rekap Hasil Analis 3

\begin{tabular}{|c|l|l|c|c|}
\hline \multirow{2}{*}{$\begin{array}{c}\text { Aspek } \\
\text { Penilaian }\end{array}$} & $\begin{array}{c}\text { Jml } \\
\text { Skor }\end{array}$ & $\begin{array}{c}\text { Rera } \\
\text { ta }\end{array}$ & Ket \\
\hline \multirow{2}{*}{ Ori } & Pre & 164 & 1,82 & SKK \\
\cline { 2 - 5 } & Post & 298 & 3,31 & SK \\
\hline \multirow{2}{*}{ Flue } & Pre & 186 & 1,55 & SKK \\
\cline { 2 - 5 } & Post & 383 & 3,19 & K \\
\hline \multirow{2}{*}{ Flex } & Pre & 179 & 1,99 & SKK \\
\cline { 2 - 5 } & Post & 334 & 3,71 & SK \\
\hline \multirow{2}{*}{ Elab } & Pre & 155 & 1,72 & SKK \\
\cline { 2 - 5 } & Post & 294 & 3,27 & SK \\
\hline \multirow{2}{*}{ Red } & Pre & 98 & 1,63 & SKK \\
\cline { 2 - 5 } & Post & 191 & 3,18 & K \\
\hline
\end{tabular}

Berdasarkan hasil penilaian kreativitas berwirausaha dari semua analis menunjukan terdapat peningkatan skor dan rerata setelah 
siswa menggunakan multimedia pembelajaran interaktif PKK. Adapun rincian skor dan rerata tiap aspek dituangkan pada tabel 6 .

Tabel 1. Rekap Hasil Keseluruhan

\begin{tabular}{|c|l|l|c|c|}
\hline \multirow{2}{*}{$\begin{array}{c}\text { Aspek } \\
\text { Penilaian }\end{array}$} & $\begin{array}{c}\text { Jml } \\
\text { Skor }\end{array}$ & $\begin{array}{c}\text { Rera } \\
\text { ta }\end{array}$ & Ket \\
\hline \multirow{2}{*}{ Ori } & Pre & 496 & 1,84 & SKK \\
\cline { 2 - 5 } & Post & 899 & 3,33 & SK \\
\hline \multirow{2}{*}{ Flue } & Pre & 561 & 1,56 & SKK \\
\cline { 2 - 5 } & Post & 1155 & 3,21 & K \\
\hline \multirow{2}{*}{ Flex } & Pre & 537 & 1,99 & SKK \\
\cline { 2 - 5 } & Post & 1004 & 3,72 & SK \\
\hline \multirow{2}{*}{ Elab } & Pre & 465 & 1,72 & SKK \\
\cline { 2 - 5 } & Post & 885 & 3,28 & SK \\
\hline \multirow{2}{*}{ Red } & Pre & 295 & 1,63 & SKK \\
\cline { 2 - 5 } & Post & 576 & 3,2 & K \\
\hline
\end{tabular}

Selanjutnya untuk gambaran perbandingan perbandingan rerata pretest dan posttest digambarkan pada gambar grafik di bawah ini:

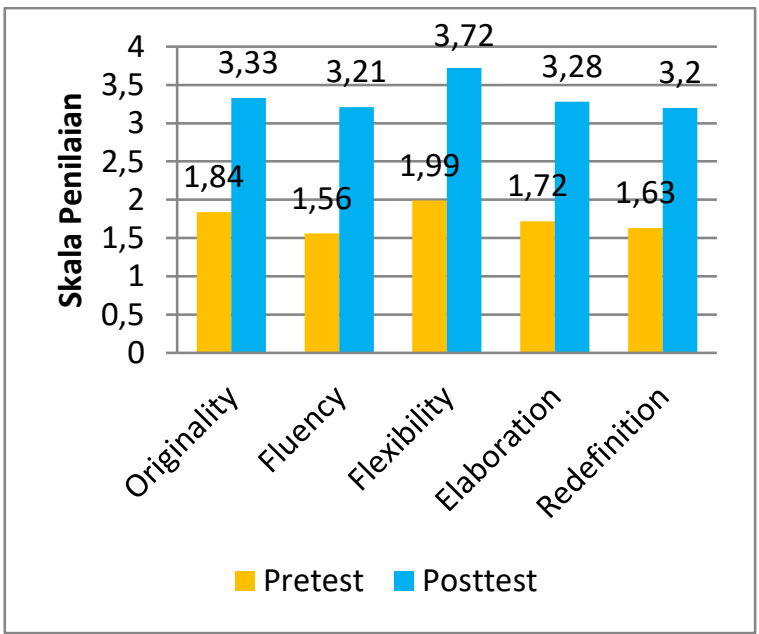

Gambar 1. Perbandingan Rerata Skor Pretest dan Posttest

Jika dilihat dari aspek originality (keaslian), sebelum menggunakan multimedia siswa memperoleh rerata skor sebesar 1,84 dengan kriteria Sangat Kurang Kreatif dan setelah menggunakan multimedia pembelajaran interaktif PKK rerata skor mengalami peningkatan menjadi 3,33 dan masuk ke dalam kriteria Sangat Kreatif. Pada aspek fluency (kelancaran) perolehan rerata skor sebelum dan sesudah menggunakan multimedia adalah 1,56 dengan kriteria Sangat Kurang Kreatif dan mengalami peningkatan menjadi 3,21 yang masuk pada kriteria Kreatif.

Aspek flexibility (keluwesan) sebelum diberikan multimedia memperoleh rerata skor 1,99 dengan dengan kriteria Sangat Kurang Kreatif dan mengalami peningkatan menjadi 3,72 dengan kriteria Sangat Kreatif. Aspek elaboration (penguraian) sebelum diberikan multimedia memiliki rerata skor 1,72 dengan kriteria Sangat Kurang Kreatif mengalami peningkatan menjadi 3,28 dengan kriteria Sangat Kreatif dan aspek redefinition (perumusan kembali) sebelum diberikan modul memiliki rerata 1,63 dengan kriteria Sangat Kurang Kreatif mengalami peningkatan menjadi 3,2 dengan kriteria Kreatif.

Kegiatan analisis berikutnya yaitu dengan melihat perbedaan pretest dan posttest menggunakan uji wilcoxon. Analisis dilakukan untuk menguji perbedaan rerata kreativitas berwirausaha siswa antara sebelum dan sesudah menggunakan produk multimedia pembelajaran interaktif PKK. Pengujian dilakukan menggunakan SPSS 24. Hasil perhitungan uji wilcoxon dituangkan pada tabel di bawah ini:

Tabel 7. Hasil Uji Wilcoxon Test Statistics ${ }^{\mathrm{a}}$

\begin{tabular}{lr|r|r|r|r} 
& $\begin{array}{c}\text { Ori_Post - } \\
\text { Ori_Pre }\end{array}$ & $\begin{array}{c}\text { Fluent_Post - } \\
\text { Fluent_Pre }\end{array}$ & $\begin{array}{c}\text { Flex_Post - } \\
\text { Flex_Pre }\end{array}$ & $\begin{array}{c}\text { Ela_Post - } \\
\text { Ela_Pre }\end{array}$ & $\begin{array}{c}\text { Redef_Post - } \\
\text { Redef_Pre }\end{array}$ \\
\hline Z & $-4.788^{\mathrm{b}}$ & $-4.786^{\mathrm{b}}$ & $-4.793^{\mathrm{b}}$ & $-4.789^{\mathrm{b}}$ & $-4.790^{\mathrm{b}}$ \\
\hline Asymp. Sig.(2-talled) & .000 & .000 & .000 & .000 & .000 \\
\hline
\end{tabular}

Hasil perhitungan tersebut diperoleh nilai Asymp.Sig. (2-tailed) 0,000 pada semua aspek kreativitas berwirausaha, yang berarti bahwa nilai Asymp.Sig. (2-tailed) pretest dan posttest kurang dari atau lebih kecil dari 0,05. Bedasarkan dasar pemberian keputusan dalam pengujian, jika nilai Asymp.Sig. (2-tailed) < 0,05 maka hipotesis alternatif (Ha) diterima dan hipotesis alternatif (Ho) ditolak. Hal ini berarti terdapat perbedaan kreativitas berwirausaha siswa antara sebelum dan sesudah menggunakan multimedia pembelajaran interaktif PKK yang telah dikembangkan. 


\section{Pembahasan}

Menurut Surasmi (2016: 593) penggunaan multimedia dalam proses pembelajaran merupakan upaya membuat suasana belajar kreatif dan inovatif dan dapat merubah tingkah laku siswa yang dapat diukur dan diamati. Melalui hasil nilai dan uji wilcoxon pretest-posttest terhadap lima aspek kreativitas berwirausaha yaitu originality (keaslian), fluency (kelancaran), flexibility (keluwesan), elaboration (penguraian) dan redefinition (perumusan kembali) dapat diketahui bahwa kelima aspek tersebut mengalami peningkatan skor rerata.

Hasil pretest aspek originality (keaslian), memperoleh rerata 1,84 dengan kriteria Sangat Kurang Kreatif dan untuk hasil posttest memperoleh rerata 3,33 dengan kriteria Sangat Kreatif. Pada aspek fluency (kelancaran) hasil pretest perolehan rerata adalah 1,56 dengan kriteria Sangat Kurang Kreatif dan posttest 3,21 dengan kriteria Kreatif. Aspek flexibility (keluwesan) pretest memperoleh rerata 1,99 dengan dengan kriteria Sangat Kurang Kreatif dan posttest 3,72 dengan kriteria Sangat Kreatif.

Aspek elaboration (penguraian) pretest memiliki rerata 1,72 dengan kriteria Sangat Kurang Kreatif dan posttest 3,28 dengan kriteria Sangat Kreatif dan aspek redefinition (perumusan kembali) pretest memiliki rerata 1,63 dengan kriteria Sangat Kurang Kreatif dan posttest 3,2 dengan kriteria Kreatif. Selanjutnya untuk hasil perhitungan melalui SPSS 24 dengan menggunakan uji Wilcoxon memperoleh nilai Asymp.Sig. (2-tailed) 0,000 di semua aspek kreativitas berwirausaha yang berarti nilai Asymp.Sig. (2-tailed) lebih kecil dari 0,05. Bedasarkan dasar pemberian keputusan dalam pengujian, jika nilai Asymp.Sig. (2-tailed) $<0,05$ maka hipotesis alternatif (Ha) diterima.

Dari kedua analisis pengujian tersebut diketahui bahwa terdapat perbedaan kreativitas berwirausaha siswa sebelum dan sesudah menggunakan multimedia pembelajaran interaktif PKK yang berarti bahwa multimedia pembelajaran interaktif PKK terbukti efektif untuk meningkatkan kreativitas berwirausaha siswa pada proses pembelajaran Mata Pelajaran PKK. Pujiriyanto (2018) memaparkan bahwa pengembangan kreativitas memerlukan proses belajar sambil mengalami, mengandung kebebasan bereksplorasi dan beraktualisasi.

Multimedia pembelajaran interaktif PKK menyuguhkan berbagai macam sumber belajar yang menginspirasi dimana siswa bebas memilih sumber mana yang paling sesuai dengan keinginan mereka. Hal tersebut mampu untuk merangsang kreativitas yang ada pada diri siswa. Menurut Budiningsih (2015: 76) kebebasan merupakan unsur penting untuk mengembangkan kreativitas dan produktivitas belajar siswa.

Integrasi hasil teknologi dan pembelajaran PKK berupa multimedia pembelajaran interaktif PKK menjadikan pembelajaran menjadi efektif dan efisien. Siwa dapat belajar secara mandiri ataupun kelompok. Selain itu, pembelajaran dapat dilakukan dimana saja dan kapan saja sesuai keinginan dan kebutuhan siswa. Hal ini diperkuat pendapat dari Gunawan (2017) yang mengatakan penggunaan teknologi dan sumber daya baru mampu untuk meningkatkan dan mempertahankan siswa dalam berpikir kreatif.

\section{PENUTUP}

Berdasarkan hasil penelitian dan pembahasan yang telah dipaparkan sebelumnya, maka dapat disimpulkan bahwa multimedia pembelajaran interaktif PKK terbukti efektif untuk meningkatkan kreativitas berwirausaha siswa pada proses pembelajaran Mata Pelajaran PKK. Hal ini ditunjukan dari hasil analisis skor rerata pretest posttest yang mengalami peningkatan dan hasil pengujian uji Wilcoxon yang memperoleh nilai Asymp.Sig. (2-tailed) 0,000 di semua aspek kreativitas berwirausaha. Peningkatan kreativitas berwirausaha siswa akan membuat tujuan pembelajaran PKK tercapai secara maksimal. 


\section{DAFTAR PUSTAKA}

Basrowi. (2016). Kewirausahaan untuk Perguruan Tinggi. Bogor: Ghalia Indonesia.

Budiningsih, A. (2015). Buku PEKERTI (Teori belajar dan Motivasi). Yogyakarta: UNY.

Dantes, N. (2017). Desain Eksperimen dan Analisis Data. Depok: Rajawali Pers.

Darmawan, D. (2011). Teknologi Pembelajaran. Bandung: PT Remaja Rosdakarya.

Daryanto. (2010). Media Pembelajaran. Bandung: Sarana Tutorial Nurani Sejahtera.

Gunawan. (2017). Keterampilan Berpikir dalam Pembelajaran Sains. Mataram: Arga Puji Press.

Hackbarth, S. (1996). The Educational Technology Handbook. New Jersey: Educational Technology Publishing.

Hujair, A. H. (2013). Media Pembelajaran Interaktif-Inovatif. Yogyakarta: Kaukaba Dipantara.

King, F. J., et., al. (2013). Higher Order Thinking Skills. Diakses melalui www.cala.fsu.edu, 4 Januari 2020.

Martin, B. L. \& Briggs, L. J. (1986). The Cognitive and Affective Domains: Integration for Instruction and Research. New Jersey: Educational Technology Publishing.

Morris, Wayne. (2006). Creativity: its Place in Education. New Zealand. Jpb. Com

Munir, M. I. T. (2010). Kurikulum Berbasis Teknologi Informasi dan Komunikasi. Bandung: Alfabeta.

National Council for Research into Vocational Education USA (1981). Toward a Theory of Vocational Educational. Columbus, Ohio: NCRVE Publication.

Otte, R.W. (1966). Creativity in Teaching: Childhood Education Volume 43 (1), pp 40-43 Taylor fracis Online. http://www.tandfonline.com/ DOI 10.1080/00094056.1966.10728017

Pujiriyanto. (2018). Desain Pembelajaran Kewirausahaan Berbasis Proyek (KWU-
PBP) untuk Meningkatkan Kreativitas Wirausaha. Disertasi. Universitas Sebelas Maret, Surakarta.

Sadiman, A. S, et al. (2006). Media pendidikan. Jakarta: PT Raja Grafindo Persada.

Saputri, D. R., \& Hikmah, S.( Maret 2019). Upaya Memperbaiki Kemampuan Berpikir Kreatif melalui Multimedia Interaktif disajikan dalam Seminar Nasional Pendidikan Dasar Universitas Muhammadiyah Purworejo.

Sarwa. (2018). Pengembangan Teknopreneneurship untuk Mata Pelajaran Produk Kreatif dan Kewirausahaan dalam Implementasi Kurikulum SMK Revisi 2016. Seminar Nasional Asosiasi Pendidikan Teknologi dan Kejuruan Indonesia (APTEKINDO), N8-10.

Smaldino, S. E., et., al. (2011). Teknologi Pembelajaran dan Media untuk Belajar. (Terjemahan Arif Rahman). Jakarta: Kencana Prenada Media Group. (Edisi asli diterbitkan oleh PEARSON Prentice Hall).

Sugiyono. (2012). Metode Penelitian Pendidikan dengan Pendekatan Kuantitatif, Kualitatif, dan $R \& D$. Bandung: Alfabeta.

Surasmi, W. A. (2016). Pemanfaatan Multimedia untuk Mendukung KUalitas Pembelajaran. Prosiding Temu Ilmiah Nasional Guru Ting VIII, 593 - 607.

Surjono, H. D., (2017). Multimedia Pembelajaran Interaktif: Konsep dan Pengembangan Edisi Pertama. Yogyakarta: UNY Press.

Trilling, B., \& Fadel, C. (2009). $21^{\text {st }}$ Century Skills: Learning for Life in Our Times. Jossey-Bass/Wiley.

Undang Undang RI No. 20 Tahun 2003 tentang Pendidikan Nasional pasal 18. 